\title{
Waktu Tunggu Pelayanan Rawat Jalan dengan Kepuasan Pasien Terhadap Pelayanan di Rawat Jalan RSUD Kabupaten Indramayu
}

\author{
Nur Laeliyah ${ }^{1}$, Heru Subekti ${ }^{2}$ \\ Program Diploma III Rekam Medis Fakultas Sekolah Vokasi Universitas Gadjah Mada ${ }^{1}$ \\ Fakultas Kedokteran Universitas Gadjah Mada² \\ Email: nur.laeliyah@mail.ugm.ac.id ${ }^{1)}$, herusubekti@ugm.ac.id ${ }^{2)}$
}

\begin{abstract}
ABSTRAK
Latar Belakang: Waktu tunggu pelayanan merupakan masalah yang masih banyak dijumpai dalam praktik pelayanan kesehatan, dan salah satu komponen yang potensial menyebabkan ketidakpuasan adalah menunggu dalam waktu yang lama. Lamanya waktu tunggu pasien merupakan salah satu hal penting dalam menentukan kualitas pelayanan kesehatan. Berdasarkan hasil studi pendahuluan yang telah dilakukan di RSUD Kabupaten Indramayu diketahui bahwa pelaksanaan pelayanan pasien di rawat jalan sendiri masih belum berjalan dengan baik dan kurang maksimal khususnya yang terjadi pada pasien lama rawat jalan.
\end{abstract}

Tujuan: Mengetahui waktu tunggu pelayanan pasien di rawat jalan, tingkat kepuasan pasien rawat jalan terhadap pelayanan di rawat jalan, dan hubungan antara waktu tunggu pelayanan pasien di rawat jalan dengan kepuasan pasien terhadap pelayanan di rawat jalan.

Metode: Jenis penelitian deskriptif dengan pendekatan kuantitatif, dan rancangan cross sectional. Teknik sampel yang digunakan yaitu purposive sampling. Instrumen penelitian ini antara lain kuesioner, check list observasi, dan penilaian observasi waktu. Analisis data menggunakan analisis univariat dan analisis bivariat dengan uji chi-square.

Hasil: Rerata waktu tunggu pelayanan pasien di rawat jalan RSUD Kabupaten Indramayu selama 70,18 menit dan sebagian besar kategori waktu lama (> 60 menit). Tingkat kepuasan dalam kategori cukup puas, berdasarkan lima dimensi kualitas mutu pelayanan didapatkan pada dimensi tangibles, responsiveness, assurance, dan emphaty dalam kategori cukup puas sedangkan pada dimensi reliability dalam kategori puas. Adanya hubungan antara waktu tunggu pelayanan pasien di rawat jalan dengan kepuasan pasien terhadap pelayanan di rawat RSUD Kabupaten Indramayu, ditunjukkan dengan nilai $p=0,042$ atau nilai korelasichi-square sebesar 4,135.

Kata Kunci: Waktu tunggu, Pelayanan rawat jalan, Pasien lama rawat jalan, Kepuasan pasien.

\begin{abstract}
Background: The waiting time care is an issue that is still prevalent in health care practices, and one component that could potentially cause dissatisfaction, where the wait for a long time causing dissatisfaction with patients. waiting time of patients in obtaining health services is one of the important and largely determine the quality of health services provided by a health care unit. Improving quality of care is a top priority in a hospital management, to reflect how hospitals manage service components that are tailored to the patient's situation and expectations. Each hospital was basically developed to meet the needs and patient satisfaction as a customer. Based on the results of preliminary studies that have been conducted by researchers at the Indramayu District Hospital. The results that the implementation will be the waiting time of patient care in outpatient still has not gone well and less than the maximum especially those that occur in older patients outpatient.

Objectives: To determine the waiting time of patients in outpatient care, outpatient satisfaction level with the services in outpatient care, and the relationship between the waiting time of patients in outpatient care with patient satisfaction with care on an outpatient basis.

Methods: This type of research is descriptive with quantitative approach, and the study design was cross-sectional. Sampling technique used is purposive sampling. The research instruments include a questionnaire, check list of observation, assessment and observation time. Analysis of the data in this study using univariate and bivariate analysis using Chi-Square.

Results: The average waiting time of patient care in outpatient hospitals district of Indramayu for 70.18 minutes and most are still in the category of long time (>60 minutes). The level of patient satisfaction with the services in the outpatient Indramayu District Hospital is still in the category quite satisfied, based on the five dimensions of quality of service quality obtained in tangibles dimension, responsiveness, assurance, and empathy in the category quite satisfied while the reliability dimension in the category are satisfied. The existence of a relationship between the waiting time of patients in outpatient care with patient satisfaction with hospital care services in Indramayu district, indicated by the value $p=0,042$ or chi-square correlation value of 4.13 .
\end{abstract}

Key World: The waitng time, The services of outpatient, Old patients, Patients satisfaction. 


\section{PENDAHULUAN}

Waktu tunggu pelayanan merupakan masalah yang masih banyak dijumpai dalam praktik pelayanan kesehatan, dan salah satu komponen yang potensial menyebabkan ketidakpuasan, dimana dengan menunggu dalam waktu yang lama menyebabkan ketidakpuasan terhadap pasien. Menurut Buhang (2007), dikaitkan dengan manajemen mutu, aspek lamanya waktu tunggu pasien dalam mendapatkan pelayanan kesehatan merupakan salah satu hal penting dan sangat menentukan kualitas pelayanan kesehatan yang diberikan oleh suatu unit pelayanan kesehatan, sekaligus mencerminkan bagaimana rumah sakit mengelola komponen pelayanan yang disesuaikan dengan situasi dan harapan pasien. Dalam segi konteks, waktu tunggu adalah masalah yang selalu menimbulkan keluhan pasien di beberapa rumah sakit, seringkali masalah waktu menunggu pelayanan ini kurang mendapatkan perhatian oleh pihak manajemen rumah sakit. Suatu rumah sakit mengabaikan lama waktu tunggu dalam pelayanan kesehatannya maka secara totalitas kualitas pelayanan rumah sakit dianggap tidak profesional dan dapat menurunkan kepuasan pasien sekaligus keluarga pasien.

Setiap rumah sakit pada dasarnya dikembangkan untuk memenuhi kebutuhan dan kepuasan pasien sebagai pelanggan hal ini juga berlaku di RSUD Kabupaten Indramayu. Peningkatan mutu pelayanan merupakan prioritas utama dalam sebuah manajemen rumah sakit, salah satu dimensi mutu pelayanan kesehatan adalah akses terhadap pelayanan yang ditandai dengan waktu tunggu pasien yang cepat (Buhang, 2007). Menurut Tjiptono (2007), mengidentifikasikan lima dimensi kualitas mutu pelayanan, antara lain tangible (berwujud), reliability (keandalan), responsiveness (daya tanggap), assurance (jaminan/keyakinan), emphaty (kesediaan untuk perduli).

Waktu tunggu pelayanan adalah waktu yang digunakan pasien untuk mendapatkan pelayanan kesehatan mulai tempat pendaftaran sampai masuk ke ruang pemeriksaan dokter. Menurut Kapustiak (2002), waktu tunggu merupakan total waktu yang digunakan oleh pasien menunggu di poliklinik, terhitung dari pasien mendaftar sampai pasien dipanggil/masuk ke ruang poliklinik (Kapustiak, 2000). Berdasarkan Kepmenkes RI No.129/Menkes/SK/IV/2008 pada pelayanan rawat jalan untuk indikator waktu tunggu pelayanan di rawat jalan yaitu 60 menit dimulai dari pasien mendaftar sampai diterima/dilayani oleh dokter spesialis. Berdasarkan hasil studi pendahuluan yang telah dilakukan oleh peneliti melalui wawancara terkait waktu tunggu pelayanan pasien rawat jalan di poliklinik dan melakukan observasi atau pengamatan bersamaan dengan saat magang/pengabdian pada bulan Juli Agustus 2015 di RSUD Kabupaten Indramayu. Hasil yang didapat terkait hal tersebut bahwa di dalam pelaksanaan akan waktu tunggu pelayanan pasien di rawat jalan sendiri masih belum berjalan dengan baik dan kurang maksimal khususnya yang terjadi pada pasien lama rawat jalan.

Akibatnya masih terlihat beberapa yang pasiennya menunggu lama untuk mendapatkan pelayanan di rawat jalan dimulai dari pasien mendaftar sampai dengan pasien dipanggil/masuk ke ruang poliklinik, yang pada akhirnya pun secara tidak langsung akan berdampak pada kepuasan pasien terhadap pelayanan yang diberikan di rawat jalan (mulai dari mendaftar sampai dengan dipanggil/masuk ke ruang poliklinik). Tidak sedikit masih dijumpai adanya komplain/keluhan dari beberapa pasien karena masalah waktu menunggu di poliklinik tujuan agar mendapatkan pelayanan medis secepatnya, sehingga kondisi pasien pun masih terlihat begitu padat/crowded, dan pasien terlihat bosan dan gelisah karena mengingat adanya keterbatasan waktu selama pelayanan di rawat jalan, sehingga masih dijumpai beberapa pasien yang menanyakan kembali ke petugas pendaftaran maupun petugas poliklinik terkait pelayanan di rawat jalan.

Rumusan masalah yang akan dibahas dalam penelitian ini yaitu "Bagaimana Hubungan antara Waktu Tunggu Pelayanan Rawat Jalan dengan Kepuasan Pasien terhadap Pelayanan di Rawat Jalan RSUD Kabupaten Indramayu?". Tujuan penelitian ini antara lain mengetahui waktu tunggu pelayanan pasien di rawat jalan, tingkat kepuasan pasien rawat jalan terhadap pelayanan di rawat jalan berdasarkan lima dimensi kualitas mutu 
pelayanan, dan hubungan antara waktu tunggu pelayanan pasien di rawat jalan dengan kepuasan pasien terhadap pelayanan di rawat jalan.

\section{METODE PENELITIAN}

Jenis penelitian ini adalah penelitian deskriptif dengan pendekatan kuantitatif, dan rancangan penelitian yaitu cross sectional. Populasi dalam penelitian ini adalah rata-rata per bulan seluruh pasien lama rawat jalan tahun 2015 yang telah mendaftar di Tempat Pendaftaran Pasien Lama Rawat Jalan RSUD Kabupaten Indramayu. Besar sampel yang digunakan sebanyak 92 responden yang diambil dengan teknik sampel purposive sampling.

Analisis data yang digunakan dalam penelitian ini adalah analisis univariat dan analisis bivariat. Analisis univariat digunakan dengan tujuan untuk mengetahui distribusi frekuensi dan presentasi variabel waktu dan kepuasan pasien.

Analisis bivariat digunakan untuk mengetahui hubungan antara dua variabel serta menguji pembuktian hipotesis penelitian akan ada tidaknya hubungan tersebut dengan tabel silang uji Chi-Square.

\section{HASIL DAN PEMBAHASAN}

\section{A. Karakteristik Responden}

Berdasarkan pengambilan data yang telah dilakukan melalui kuesioner terhadap 92 orang responden di RSUD Kabupaten Indramayu, pada tabel 1. menunjukkan bahwa hasil karakteristik responden pada penelitian ini mayoritas berumur 28-37 tahun sebanyak 28 orang $(30,4 \%)$, berjenis kelamin perempuan sebanyak 52 orang $(56,5 \%)$, jenis pekerjaan diluar dari pilihan (ibu rumah tangga, supir, petani, dan lainlain) yang ada sebanyak 35 orang $(38,0 \%)$, berpendidikan terakhir SMA sebanyak 31 orang $(33,7 \%)$, dan pasien dengan cara bayar BPJS sebanyak 59 orang $(64,1 \%)$.

\section{B. Hasil Penelitian}

1. Waktu Tunggu Pelayanan Pasien di Rawat Jalan

Tabel 1. Frekuensi Waktu Tunggu Pelayanan Pasien di Rawat Jalan RSUD Kabupaten Indramayu

\begin{tabular}{cccc}
\hline No & $\begin{array}{c}\text { Kategori Waktu } \\
\text { Tunggu Rawat Jalan (orang) }\end{array}$ & Jumlah & Persentase \\
\hline 1 & 60 menit & 43 & 46,7 \\
2 & $>60$ menit & 49 & 53,3 \\
\hline & Total & 92 & 100 \\
\hline
\end{tabular}

Tabel 1. menunjukkan bahwa dari

92 orang responden diperoleh bahwa rata-rata waktu tunggu pelayanan pasien lama di rawat jalan RSUD Kabupaten Indramayu selama 70,18 menit. Ditinjau berdasarkan standar pelayanan minimal (SPM) untuk indikator waktu tunggu pasien di rawat jalan, diperoleh bahwa waktu tunggu 60 menit (kategori cepat) dijumpai sebanyak 43 orang pasien lama rawat jalan $(46,7 \%)$ sedangkan waktu tunggu $>$ 60 menit (kategori lama) dijumpai sebanyak 49 orang pasien lama rawat jalan $(53,3 \%)$,

Selain karena faktor tertentu dari jumlah pasien rawat jalan yang berkunjung/berobat, dan kondisi penyediaan berkas rekam medis pasien rawat jalan, hal penting yang mempengaruhi waktu tunggu pelayanan pasien di rawat jalan adalah dari pihak RSUD Kabupaten Indramayu sendiri tidak adanya manajemen yang mangatur atau membuat regulasi dalam bentuk prosedur tetap/SOP (Standar Operating Perocedure).

Terutama dalam hal penetapan waktu minimal pasien menunggu untuk mendapatkan pelayanan di rawat jalan yang diberlakukan. Faktor lain yang mempengaruhi waktu tunggu pelayanan pasien di rawat jalan RSUD Kabupaten Indramayu berdasarkan hasil penelitian, didapatkan dari teknisi kinerja para petugas dalam memberikan pelayanan pasien di rawat jalan Diantaranya kurangnya kedisiplinan dalam memulai dan mengakhiri pelayanan kepada pasien di rawat jalan, kurangnya rasa kerjasama yang terjalin antar para petugas dalam melaksanakan pelayanan di rawat jalan (petugas rekam medis, petugas poliklinik, perawat, dokter) sekaligus kesadaran para petugas akan pentingnya waktu tunggu pelayanan pasien di rawat jalan. Mengatasi masalah tersebut dapat dilakukan dengan peningkatan dalam kedisiplinan para petugas agar dapat terjalinnya kerjasama antar para petugas (petugas rekam medis, petugas poliklinik, perawat, dokter) dalam melaksanakan pelayanan di rawat jalan kepada pasiennya. 
2. Tingkat Kepusan Pasien Rawat Jalan terhadap Pelayanan di Rawat Jalan

Pengukuran tingkat kepuasan pasien atau keluarga pasien lama rawat jalan terhadap pelayanan di rawat jalan dilakukan terhadap 92 orang responden berdasarkan kuesioner yang berisi 17 butir item pernyataan yang telah terkumpul, ditabulasi dan dilakukan analisis statistik. Pada tabel 2. menunjukkan bahwa secara keseluruhan untuk tingkat kepuasan pasien lama rawat jalan terhadap pelayanan di rawat jalan RSUD Kabupaten Indramayu sebanyak 3 orang $(3,3 \%)$ yang menyatakan tidak puas, sebanyak 73 orang $(79,3 \%)$ yang menyatakan cukup puas, sebanyak 14 orang $(15,2 \%)$ yang menyatakan puas, dan sebanyak 2 orang $(2,2 \%)$ yang menyatakan sangat puas Dilihat dari nilai rerata (mean) tingkat kepuasan pasien lama rawat jalan terhadap pelayanan di rawat jalan RSUD Kabupaten Indramayu diperoleh hasil sebesar 3,163 artinya terletak pada interval kelas 2,601 - 3,400 sehingga termasuk dalam kategori cukup puas.

Tabel 2. Frekuensi Tingkat Kepuasan Pasien Rawat Jalan terhadap Pelayanan di Rawat Jalan RSUD Kabupaten Indramayu

\begin{tabular}{|c|c|c|c|c|}
\hline No & $\begin{array}{l}\text { Kategori } \\
\text { Kepuasan } \\
\text { Pasien }\end{array}$ & $\begin{array}{l}\text { Rentang } \\
\text { Skor }\end{array}$ & $\begin{array}{c}\text { Jumlah } \\
\text { (orang) }\end{array}$ & $\%$ \\
\hline 1 & Tidak Puas & $\begin{array}{c}1,801- \\
2,600\end{array}$ & 3 & 3,3 \\
\hline 2 & Cukup Puas & $\begin{array}{c}2,601- \\
3,400\end{array}$ & 73 & 79,3 \\
\hline 3 & Puas & $\begin{array}{c}3,401- \\
4,200\end{array}$ & 14 & 15,2 \\
\hline 4 & Sangat Puas & $\begin{array}{c}4,201- \\
5,000\end{array}$ & 2 & 2,2 \\
\hline & Total & & 92 & 100 \\
\hline & $\begin{array}{l}\text { Rerata } \\
(\text { mean })\end{array}$ & & & 3,163 \\
\hline
\end{tabular}

a. Tangibles (Berwujud)

Tingkat kepuasan pasien lama rawat jalan terhadap pelayanan di rawat jalan RSUD Kabupaten Indramayu pada dimensi tangible (berwujud) sebanyak 10 orang $(10,9 \%)$ yang menyatakan tidak puas, sebanyak 49 orang $(53,3 \%)$ yang menyatakan cukup puas, sebanyak 29 orang (31,5\%) yang menyatakan puas, dan sebanyak 4 orang $(4,3 \%)$ yang menyatakan sangat puas. Dilihat dari nilai rerata (mean) yang diperoleh sebesar 3,293 artinya terletak pada interval kelas 2,601 - 3,400 sehingga termasuk dalam kategori cukup puas.

b. Reliability Reliability (Keandalan)

Tingkat kepuasan pasien lama rawat jalan terhadap pelayanan di rawat jalan RSUD Kabupaten Indramayu pada dimensi reliability (keandalan) sebanyak 49 orang (53,3\%) yang menyatakan cukup puas, sebanyak 42 orang $(45,7 \%)$ yang menyatakan puas, dan sebanyak 1 orang $(1,1 \%)$ yang menyatakan sangat puas Dilihat dari nilai rerata (mean) yang diperoleh sebesar 3,478 artinya terletak pada interval kelas 3,401 - 4,200 sehingga termasuk dalam katgori puas.

c. Responsiveness (Daya Tanggap)

Tingkat kepuasan pasien lama rawat jalan terhadap pelayanan di rawat jalan RSUD Kabupaten Indramayu pada dimensi responsiveness (daya tanggap) sebanyak 5 orang $(5,4 \%)$ yang menyatakan tidak puas, sebanyak 61 orang $(66,3 \%)$ yang menyatakan cukup puas, sebanyak 24 orang $(26,1 \%)$ yang menyatakan puas, dan sebanyak 4 orang (2,2\%) yang menyatakan sangat puas. Dilihat dari nilai rerata (mean) yang diperoleh sebesar 3,250 artinya terletak pada interval kelas 2,601 3,400 sehingga termasuk dalam kategori cukup puas.

d. Assurance (Jaminan / Keyakinan)

Tingkat kepuasan pasien lama rawat jalan terhadap pelayanan di rawat jalan RSUD Kabupaten Indramayu pada dimensi assurance sebanyak 6 orang $(6,5 \%)$ yang menyatakan tidak puas, sebanyak 60 orang $(65,2 \%)$ yang menyatakan cukup puas, sebanyak 24 orang $(31,5 \%)$ yang menyatakan puas, dan sebanyak 4 orang $(4,3 \%)$ yang menyatakan sangat puas Dilihat dari nilai rerata (mean) yang diperoleh sebesar 3,239 artinya terletak pada interval kelas 2,601 - 3,400 sehingga termasuk dalam kategori cukup puas. 
e. Emphaty (Kesediaan untuk Perduli)

Tingkat kepuasan pasien lama rawat jalan terhadap pelayanan di rawat jalan RSUD Kabupaten Indramayu pada dimensi emphaty (kesediaan untuk perduli) sebanyak 13 orang $(14,1 \%)$ yang menyatakan tidak puas, sebanyak 55 orang $(59,8 \%)$ yang menyatakan cukup puas, sebanyak 21 orang $(22,8 \%)$ yang menyatakan puas, dan sebanyak 3 orang $(3,3 \%)$ yang menyatakan sangat puas Dilihat dari nilai rerata (mean) yang diperoleh sebesar 3,152 artinya terletak pada interval kelas 2,601 - 3,400 sehingga termasuk dalam kategori cukup puas.

3. Hubungan antara Waktu Tunggu Pelayanan Pasien di Rawat Jalan dengan Kepuasan Pasien terhadap Pelayanan di Rawat Jalan Uji hipotesis pada variabel bebas dan berdasarkan hasil analisis uji statistik dengan menggunakan chi-square pada penelitian ini diperoleh nilai asymp. Sign atau $p=0,042$ yang menunjukkan bahwa nilai $p<0,05$ maka Ha diterima. Selain itu dapat juga dilihat pada hasil nilai korelasi chi-square $_{\text {itung }}=4,135$ yang menunjukkan bahwa nilai korelasi chisquare $_{\text {hitung }}>$ chi- square $_{\text {tabel }}(3,84)$ maka $\mathrm{H}_{0}$ ditolak, sehingga hasil dalam pengambilan keputusan uji hipotesis dalam penelitian ini yaitu adanya hubungan antara waktu tunggu pelayanan pasien di rawat jalan dengan kepuasan pasien terhadap pelayanan di rawat jalan RSUD Kabupaten Indramayu.

\section{Pembahasan}

1. Waktu Tunggu Pelayanan Pasien di Rawat Jalan

Waktu tunggu merupakan total waktu yang digunakan oleh pasien menunggu di poliklinik, terhitung dari pasien mendaftar sampai pasien dipanggil/masuk ke masing-masing ruang poliklinik (Kapustiak, 2000). Menurut Kepmenkes RI No.129/Menkes/SK/IV/2008

pelayanan rawat jalan dengan indikator waktu tunggu pelayanan di rawat jalan adalah waktu yang diperlukan mulai pasien mendaftar sampai dengan diterima/dilayani oleh dokter spesialis yaitu 60 menit. Ditinjau berdasarkan standar pelayanan minimal (SPM) dengan indikator waktu tunggu pelayanan di rawat jalan, dari hasil penelitian waktu menunggu pelayanan pasien di rawat jalan (92 orang responden) diperoleh bahwa waktu tunggu 60 menit (kategori cepat) dijumpai sebanyak 43 orang $(46,7 \%)$ sedangkan waktu tunggu $>60$ menit (kategori lama) dijumpai sebanyak 49 orang pasien rawat jalan $(53,3 \%)$.

Hasil tersebut menunjukkan bahwa waktu tunggu pelayanan pasien di rawat jalan RSUD Kabupaten masih belum sesuai karena hasil yang diperoleh sebagian besar masih jauh dari pencapaian waktu yang dijadikan sebagai target/tolok ukur, dan juga masih dalam ketegori waktu lama, dimana rata-rata waktu tunggu pelayanan yang diperoleh yaitu selama 70,18 menit. Menurut Sabarguna (2008), suatu pelayanan yang dijalankan perlu adanya standar pelayanan yang dibuatkan dalam rangka mencapai tujuan seperti dicapainya peningkatan ukuran sasaran mutu pelayanan secara timbal balik akan dicapai efisien, baik secara lisan atau secara tertulis.

Berdasarkan hasil penelitian, selain karena faktor tertentu dari jumlah pasien rawat jalan yang berkunjung/berobat, dan penyediaan berkas rekam medis pasien rawat jalan, hal penting yang mempengaruhi waktu tunggu pelayanan pasien di rawat jalan adalah dari pihak RSUD Kabupaten Indramayu sendiri tidak adanya manajemen yang mangatur atau membuat regulasi dalam bentuk prosedur tetap/SOP (Standar Operating Perocedure). Terutama dalam hal penetapan standar waktu pasien menunggu untuk mendapatkan pelayanan di rawat jalan, sehingga RSUD Kabupaten Indramayu perlu adanya prosedur tetap/SOP (Standar Operating Perocedure) terkait pelayanan di rawat jalan sekaligus menetapkan pula standar pelayanan waktu tunggu pasien di rawat jalan yang diberlakukan.

Berdasarkan Undang-undang RI No. 44 Tahun 2009 yang menyatakan bahwa rumah sakit wajib memiliki 
standar prosedur operasional dalam menyelenggarakan dan melaksanakan berbagai kegiatan dan fungsi pelayanan yang dibuat oleh sarana pelayanan kesehatan. Rumah sakit pun harus mempunyai standar waktu dalam melakukan pelayanan kesehatan tertentu, dengan adanya standar waktu tersebut diharapkan petugas mempunyai pedoman dalam melaksanakan pelayanan yang diberikan kepada pasien dan mempunyai tujuan untuk mencapai target waktu yang telah ditentukan (Sabarguna, 2008).

Faktor lain yang mempengaruhi waktu tunggu pelayanan pasien di rawat jalan RSUD Kabupaten Indramayu berdasarkan hasil penelitian, didapatkan dari teknisi kinerja para petugas dalam memberikan pelayanan pasien di rawat jalan, seperti kurangnya kedisiplinan dalam memulai dan mengakhiri pelayanan kepada pasien di rawat jalan, kurangnya rasa kerjasama yang terjalin antar para petugas dalam melaksanakan pelayanan di rawat jalan (petugas rekam medis, petugas poliklinik, perawat, dokter) sekaligus kesadaran para petugas akan pentingnya waktu tunggu pelayanan pasien di rawat jalan. Mengatasi masalah tersebut dapat dilakukan dengan peningkatan dalam kedisiplinan para petugas agar dapat terjalinnya kerjasama antar para petugas (petugas rekam medis, petugas poliklinik, perawat, dokter) dalam melaksanakan pelayanan di rawat jalan kepada pasiennya.

Aspek teknisi kinerja petugas dapat dijabarkan dalam pelayanan yang cepat, kedisiplinan petugas, keterampilan dan kemampuan petugas, dan petugas dapat dipercaya. Kedisiplinan petugas adalah suatu bentuk pelatihan yang berusaha memperbaiki dan membentuk pengetahuan, sikap, dan prilaku sehingga petugas tersebut berusaha bekerja secara kooperatif dengan para petugas lainnya serta meningkatkan dan tercapainya hasil yang maksimal dari kinerja yang dijalankan (Lusa, 2007). Menurut Buhang (2007), pelayanan yang cepat kepada pasien tidak lepas dari kerjasama antar petugas di rumah sakit.
Sebagai pembanding dan mendukung hasil penelitian, Wahono (2011) dalam penelitianya tentang Kepuasan Keluarga Pasien terhadap Waktu Tunggu Pelayanan di Instalasi Rawat Jalan RSJ Provinsi Kalimantan Barat dalam lama waktu tunggu pelayanan di instalasi rawat jalan dari 70 responden menunjukkan waktu menunggu tercepat selama 6,37 menit sedangkan waktu menunggu terlama selama 78,9 menit. Rerata dari lama waktu tunggu pelayanan adalah 36,4940 menit (SD $21,020)$, sehingga rerata lama waktu tunggu pelayanan masuk dalam kategori lama. Pembanding hasil penelitian lainnya yang juga sesuai dilakukan oleh Buhang (2007) tentang waktu tunggu di Instalasi Rawat Jalan RSUD Prof. Dr. H. Aloei Saboe Kota Gorontalo bahwa didapatkan 39\% kategori lama, 5\% menganggap terlalu lama, 38\% mengatakan sedang, dan 19\% mengatakan cepat.

2. Tingkat Kepusan Pasien Rawat Jalan terhadap Pelayanan di Rawat Jalan

Kepuasan pasien dapat ditentukan oleh berbagai jenis pelayanan yang didapatkan selama menggunakan beberapa tahapan pelayanan kesehatan. Menurut Kotler (2005), kualitas pelayanan adalah keseluruhan ciri serta sifat dari suatu hasil (pelayanan) yang berpengaruh pada kemampuannya untuk memuaskan kebutuhan yang dinyatakan atau tersirat. Dengan demikian, yang dimaksud dengan mutu pelayanan kesehatan adalah yang menunjukkan pada tingkat kesempurnaan pelayanan kesehatan dalam menimbulkan rasa puas pada diri setiap pasien.

Menurut Pohan (2007), aspekaspek yang mempengaruhi kepuasan pasien rawat jalan rumah sakit, antara lain: penampilan gedung rumah sakit meyakinkan dan menarik, lingkungan rumah sakit bersih nyaman dan teratur, pertamanan rumah sakit indah dan dipelihara dengan baik, perparkiran rumah sakit teratur dan aman, petunjuk arah dan nama ruangan yang jelas, penampilan dokter, perawat, dan petugas kesehatan lain yang rapi dan bersih serta bersikap meu menolong, 
kantor rekam medik buka tepat waktu, petugas rekam medis melayani dengan sopan, ramah, tepat waktu dan tanggap, dan poliklinik buka tepat waktu.

Berdasarkan hasil penelitian, didapatkan bahwa secara keseluruhan tingkat kepuasan pasien lama rawat jalan terhadap pelayanan yang diberikan dirawat jlan RSUD Kabupaten Indramayu (pasien mendaftar, penyediaan berkas rekam medis, pasien menunggu dipanggil/masuk ke ruang poliklinik) masih tergolong cukup puas dengan nilai rerata (mean) sebesar 2,804. Kepuasan pelanggan (pasien) memiliki hubungan dengan kualitas pelayanan dan berdasarkan dimensi kepuasan terdapat lima dimensi utama yang teridentifikasi sekaligus yang menentukan kualitas mutu pelayanan (Tjiptono (2007).

a. Tangibles (Berwujud)

Dimensi tangibles sangat penting dalam penilaian mutu pelayanan rumah sakit khususnya dalam pelayanan dirawat jalan yang diberikan kepada pasien, karena hal pertama yang menunjang kepuasan seseorang adalah kenyamana terhadap penampilan fisik dari fasilitas maupun tenaga kesehatan. Menurut Tjiptono (2007), tangibles (berwujud) meliputi penampilan fisik fasilitas, kelengkapan peralatan, personil, dan meteri komunikasi. Berdasarkan hasil penelitian, didapatkan pada dimensi tangibles (berwujud) memperoleh nilai rerata (mean) sebesar 3,293 Artinya terletak pada interval kelas 2,601 - 3,400 sehingga pada dimensi ini termasuk dalam kategori cukup puas. Pada penelitian yang dilakukan oleh Supriyadi (2007) tentang kepuasan pasien terhadap pelayanan rawat jalan di RSUD Wamena Kabupaten Jayawijaya, hasil pada dimensi tangibles menunjukkan bahwa sebesar $77,62 \%$ dimensi ini tergolong memuaskan, sehingga hasil penelitian diatas memiliki perbedaan dengan hasil penelitian yang dilakukan oleh peneliti. Hal tersebut juga didukung dari hasil observasi yang telah dilakukan di RSUD Kabupaten Indramayu, didapatkan bahwa sebagian besar kepuasan responden terhadap pelayanan pada dimensi tangibles khususnya dalam cakupan akan pelayanan dalam ketersediaan fasilitas sarana dan prasarana pendukung seperti kursi tunggu, televisi, koran/majalah, dan informasi terkait alur/prosedur palayanan yang masih belum memuaskan.

b. Reliabillity (Keandalan)

Ketepatan, ketelitian, dan kepastian dari petugas dalam memberikan pelayanan sangat penting, mengingat waktu adalah hal yang sangat berharga sehingga hal ini juga harus diperhatikan terutama dalam bidang kesehatan. Menurut Tjiptono (2007), reliability (keandalan) yaitu kemampuan untuk memberikan dan melakukan pelayanan yang dijanjikan dengan segera, terpercaya, akurat, dan memuaskan. Berdasarkan hasil penelitian, didapatkan pada dimensi reliability (keandalan) memperoleh nilai rerata (mean) sebesar 3,478. Artinya terletak pada interval kelas 2,601 - 3,400 sehingga pada dimensi ini termasuk dalam kategori puas. Memiliki persamaan dengan hasil penelitian, oleh Supriyadi (2007) dalam penelitian yang dilakukan tentang kepuasan pasien pada dimensi reliability, menunjukkan bahwa sebesar 73,24\% dimensi ini tergolong memuaskan.

c. Responsiveness (Daya Tanggap)

Merefleksikan komitmen untuk memberikan pelayanan yang tanggap akan keinginan dan kesiapan petugas untuk melayani pasien, dalam hal ini yaitu merefleksikan persiapan rumah sakit sebelum memberikan pelayanan khususnya pelayanan pasien di rawat jalan. Menurut Tjiptono (2007), responsiveness (daya tanggap) yaitu kemauan/kesigapan dan kemampuan para petugas untuk membantu pelanggan dan memberikan pelayanan dengan cepat dan tanggap. Berdasarkan hasil penelitian, didapatkan pada dimensi responsiveness (daya tanggap) memperoleh nilai rerata (mean) sebesar 3,250.

Artinya terletak pada interval kelas 2,601 - 3,400 sehingga pada dimensi ini termasuk dalam kategori cukup puas. Pada penelitian yang dilakukan oleh 
Supriyadi (2007) tentang kepuasan pasien pada dimensi responsiveness, menunjukkan bahwa sebesar 71,43\% dimensi ini tergolong memuaskan, sehingga hasil penelitian diatas memiliki perbedaan dengan hasil penelitian yang dilakukan peneliti. Hal tersebut juga didukung dari hasil observasi yang telah dilakukan di RSUD Kabupaten Indramayu, didapatkan bahwa sebagian besar kepuasan responden terhadap pelayanan pada dimensi responsiveness khususnya akan cakupan dalam pelayanan oleh petugas untuk ketanggapan, kesiapan, dan kemampuan dalam melayani komplain/masalah pasien yang masih belum memuaskan.

d. Assurances (Jaminan/Keyakinan) Jaminan/Keyakinan sangat dibutuhkan oleh pasien terutama dalam bagaimana menjalankan pelayanan yang dimana untuk menekankan pada kemampuan penyedia jasa dan membangkitkan rasa percaya dan keyakinan diri pasien bahwa pihak penyedia jasa terutama petugasnya mampu memenuhi kebutuhan pasiennya, memberikan pelayanan dengan kepastian, dan bebas dari keragu-raguan sekligus membiarkan pasien menunggu tanpa adanya suatu alasan yang jelas yang dapat menyebabkan persepsi yang negatif dalam kualitas pelayanannya. Menurut Tjiptono (2007), assurance (jaminan/keyakinan) yaitu pengetahuan, kemampuan, dan sifat yang dimiliki para petugas untuk menimbulkan kepercayaan dan keyakinan. Berdasarkan hasil penelitian, didapatkan pada dimensi assurance (jaminan/keyakinan) memperoleh nilai rerata (mean) sebesar 3,239. Artinya terletak pada interval kelas 2,601 3,400 sehingga pada dimensi ini termasuk dalam kategori cukup puas.

Sebagai pembanding hasil penelitian, kepuasan pasien terhadap pelayanan rawat jalan yang dilakukan oleh Supriyadi (2007) tentang kepuasan pasien pada dimensi assurance, menunjukkan sebesar $78,45 \%$ dimensi ini tergolong memuaskan, sehingga hasil penelitian diatas memiliki perbedaaan dengan hasil penelitian oleh peneliti. Hal tersebut juga didukung dari hasil observasi yang telah dilakukan di RSUD Kabupaten Indramayu, didapatkan bahwa sebagian besar kepuasan responden terhadap pelayanan pada dimensi assurance khususnya akan cakupan dalam pelayanan terhadap kepercayaan pasien kepada kemampuan petugas dan waktu tunggu yang rasakan selama poses pelayanan berlangsung yang mana itu semua masih belum memuaskan.

e. Emphaty (Kesediaan untuk

Perduli)

Semua pasien senantiasa ingin diperhatikan dan bersifat individual yang diberikan kepada konsumen dengan berupaya memahami keinginannya sehingga dimensi emphaty juga sangat penting. Pasien datang untuk daftar agar secepatnya mendapatkan pelayanan berobat jalan karena ingin mengutarakan atau memeriksa keluhan/penyakit yang dirasakan. Menurut Tjiptono (2007) emphaty (kesediaan untuk perduli), yaitu memberikan perhatian pribadi bagi pelanggan seperti kemudahan dalam hubungan komunikasi, usaha untuk memahami kebutuhan dan keinginan pelanggan.

Berdasarkan hasil penelitian, didapatkan pada dimensi emphaty (kesediaan untuk perduli) memperoleh nilai rerata (mean) sebesar 3,125 artinya terletak pada interval kelas 2,601 - 3,400 sehingga pada dimensi ini termasuk dalam kategori cukup puas. Sebagai pembanding hasil penelitian, kepuasan pasien terhadap pelayanan rawat jalan yang dilakukan oleh Supriyadi (2007) tentang kepuasan pasien pada dimensi emphaty, sebesar $70,14 \%$ dimensi ini tergolong memuaskan, sehingga hasil penelitian diatas memiliki perbedaan dengan hasil penelitian peneliti. Hal tersebut juga didukung dari hasil observasi yang telah dilakukan di RSUD Kabupaten Indramayu, didapatkan bahwa sebagian besar kepuasan responden pada dimensi emphaty khususnya akan cakupan dalam pelayanan petugas untuk bersikap ramah dan sopan santun, keperdulian dalam membantu, serta memberikan 
salam dan bertanya keperluan pasien yang masih belum memuaskan.

3. Hubungan antara Waktu Tunggu Pelayanan Pasien di Rawat Jalan dengan Kepuasan Pasien terhadap Pelayanan di Rawat Jalan

Dikaitkan dengan manajemen mutu, aspek lamanya waktu tunggu pasien dalam mendapatkan pelayanan kesehatan merupakan salah satu hal penting dan sangat menentukan kualitas pelayanan kesehatan yang diberikan oleh suatu unit pelayanan kesehatan (Buhang, 2007). Menurut Kotler (2002), terdapat hubungan yang erat antara kualitas (hasil) dan pelayanan, semakin tinggi tingkat kualitas (hasil) dan pelayanan menyebabkan semakin tinggi kepuasan pasien. Berdasarkan hasil penelitian, menunjukkan bahwa adanya hubungan antara waktu tunggu pelayanan pasien di rawat jalan dengan kepuasan pasien terhadap pelayanan di rawat jalan RSUD Kabupaten Indramayu dengan nilai $\rho=0,042$ atau nilai korelasi chisquare sebesar 4,135, yang berarti ada kecenderungan lamanya waktu tunggu pelayanan pasien di rawat jalan akan membuat pasien tidak puas dengan pelayanan yang diberikan di rawat jalan, dan begitupun dengan sebaliknya. Masalah tersebut dapat menjadi perhatian khusus dan perlu dilakukan pembenahan kembali bagi manajemen rumah sakit.

Menurut Munro (2006), waktu tunggu pelayanan di rumah sakit menjadi masalah yang senantiasa harus dibenahi seperti meminimalkan pasien untuk tidak terlalu lama menunggu pelayanan sehingga pasien atau keluarganya akan merasa puas terhadap pelayanan yang diberikan oleh rumah sakit, apabila pasien sudah merasa puas, kemungkinan besar akan memanfaatkan kembali pelayanan yang diterimanya tersebut. Sebagai pembanding dan mendukung hasil penelitian, oleh Wahono (2011) dalam penelitiannya tentang kepuasan keluarga pasien terhadap waktu tunggu pelayanan di instalasi rawat jalan Rumah Sakit Jiwa Provinsi Kalimantan Barat menyimpulkan bahwa terdapat hubungan yang kuat antara lama waktu tunggu dengan kepuasan keluarga pasien $(\rho<0,05)$. Penelitian lainnya yang sesuai adalah penelitian Kurniawan (2012) yang menyimpulkan bahwa ada pengaruh waktu pelayanan terhadap kepuasan pasien di Poli Penyakit Dalam RS Baptis Kediri $(\rho=0,043)$.

\section{PENUTUP}

\section{A. Kesimpulan}

1. Rerata waktu tunggu pelayanan pasien di rawat jalan RSUD Kabupaten Indramayu selama 70,18 menit dan sebagian besar masih dalam kategori waktu lama.

2. Tingkat kepuasan pasien rawat jalan terhadap pelayanan yang diberikan di rawat jalan RSUD Kabupaten Indramayu masih dalam kategori cukup puas, dilihat dari lima dimensi kualitas mutu pelayanan antara lain:
a. Pada dimensi tangibles (berwujud) dalam kategori cukup puas

b. Pada dimensi reliability (keandalan) dalam kategori puas

c. Pada dimensi responsiveness (daya tanggap) dalam kategori cukup puas
d. Pada dimensi assurance (jaminan/keyakinan) dalam kategori cukup puas

e. Pada dimensi emphaty (kesediaan untuk perduli) dalam kategori cukup puas.

3. Adanya hubungan antara waktu tunggu pelayanan pasien di rawat jalan dengan kepuasan pasien terhadap pelayanan dirawat jalan RSUD Kabupaten Indramayu, dengan hasil nilai $p=0,042$ atau nilai korelasi chi-square $_{\text {hitung }}=4,135$. Hal ini membuktikan bahwa dengan lama waktu tunggu pelayanan pasien di rawat jalan akan semakin meningkat pula rasa tidak puas pasien terhadap pelayanan yang diberikan di rawat jalan, begitupun sebaliknya.

\section{B. Saran}

Adanya kebijakan tertulis yang dikeluarkan dalam bentuk prosedur tetap/SOP (Standar Operating Perocedure) terkait pelayanan di rawat jalan RSUD Kabupaten Indramayu khususnya menetapkan akan standar 
pelayanan terhadap waktu tunggu pasien di rawat jalan yang diberlakukan, sehingga adanya pedoman dan target/sasaran bagi petugas dalam melaksanakan pelayanan.

Perlu adanya pembenahan akan waktu pelayanan yang harus pasien rasakan dengan meminimalkan waktu tunggu pasien untuk mendapatkan pelayanan di rawat jalan RSUD Kabupaten Indramayu salah satunya kedisiplinan petugas dalam yang perlu ditingkatkan kembali agar dapat terciptanya kerjasama dan meningkatkan kesadaran satu sama lain dan untuk lebih saling memperhatikan akan pentingnya akan waktu pelayanan di rawat jalan yang diberikan kepada pasiennya

Perlu adanya peningkatan kembali terkait pelayanan di rawat jalan RSUD Kabupaten Indramayu yang diberikan kepada pasiennya pada cakupan masing-masing dimensi yang masih dalam kategori cukup puas, antara lain:

a. Pada dimensi tangibles (berwujud) dalam hal ketersediaan sarana dan prasarana pendukung kepada pasiennya seperti kursi tunggu, televisi, koran/majalah, informasi terkait alur/prosedur palayanan, dan hal terkait lainnya

b. Pada dimensi responsiveness (daya tanggap) dalam hal ketanggapan dan kesiapan petugasnya dalam melayani komplain/masalah pasiennya

c. Pada dimensi assurance (jaminan/keyakinan) Dalam hal kepercayaan pasien selama berlangsungnya poses pelayanan yang diberikan terutama pada kemampuan petugasnya

d. Pada dimensi emphaty (kesediaan untuk perduli) dalam hal cara sikap petugas melayani dengan lebih ramah dan sopan santun, keperdulian dalam membantu pasien, serta pemberian salam sekaligus bertanya akan keperluan pasien.

\section{DAFTAR PUSTAKA}

Arikunto, S. (2006) Prosedur Penelitian Suatu Pendekatan Praktik. Jakarta: Rineka Cipta.
Azwar, A. (1996) Pengantar Administrasi Kesehatan. Jakarta: Binarupa Aksara.

Azwar, S. (2011) Metode Penelitian. Yogyakarta: Pustaka Pelajar.

Basuki. (2003) Manajemen Arsip Dinamis. Jakarta: Gramedia Pustaka Utama.

Budiarto, E. (2003) Metodologi Penelitian Kedokteran: Sebuah Pengantar. Jakarta: Penerbit Buku Kedokteran- EGC.

Budi, S.C. (2011) Manajemen Unit Kerja Rekam Medis. Yogyakarta: Quantum Sinergis Media.

Bungin, B. (2007) Metode Penelitian Kuantitatif. Jakarta: Kencana Prenada Media Group.

Depkes RI. (1997) Pedoman Pengelolaan Rekam Medis Rumah Sakit Di Indonesia Revisi I. Jakarta: Direktorat Jenderal Pelayanan Medik Departemen Kesehatan Republk Indonesia.

Depkes RI. (2008) Keputusan Menteri Kesehatan RI No.129/Menkes/SK/IV/2008 tentang Standar Pelayanan Minimal di Rumah Sakit. www.depkes.go.id.

Lusa, J. (2007) Mengukur Kepuasan Pasien Rumah Sakt. Internet. Tersedia dalam http://Jsofian.wordpress.com/mengu

Kotler, J.P. (2002) Manajemen Pemasaran. Yogyakarta: Prehallindo

Meloeng, L.J. (2007) Metodologi Penelitian Kualitatif. Bandung: Remaja Rosda Karya.

Notoadmodjo, S. (2012) Metode Penelitian Kesehatan. Jakarta: Rineka Cipta.

Rangkuti. F. (2006) Measuring Customer Satisfaction. Jakarta: PT. Gramedia Pustaka Umum.

Republik Indonesia. (2009) Undang-undang RI No.44/2009 tentang Rumah Sakit. Jakarta: Novindo Pustaka Mandiri.

Sabarguna, B.S. (2008) Sistem Informasi Manajemen Rumah Sakit Edisi Revisi. Yogyakarta: Konsorsium Rumah Sakit Islam Jawa Tengah dan Yogyakarta.

Santoso, S. (2011) Aplikasi dengan SPSS untuk Konsep Statistik Non Parametrik. Jakarta: PT. Elex Media Komputindo.

(2011) Aplikasi dengan SPSS untuk Konsep Statistik Parametrik. Jakarta: PT. Elex Media Komputindo.

Sugiyono. (2009) Metode Penelitian Kualitatif dan Kuantitatif dari $R \& D$. Bandung: Alfabeta

Gerson, R. (2004) Mengukur Kepuasan Pelanggan. Jakarta: PPM. 
Hartono, B. (2010) Manajemen Pemasaran untuk Rumah Sakit. Jakarta: Rineka Cipta.

Hatta, G.R. (2008) Pedoman Manajemen Informasi Kesehatan di Sarana

Huffman, E.K. (1994) Health Information Management. Illyonis: Physician Record Company. 